\title{
PENGARUH RELIGIUSITAS TERHADAP ETIKA BERBISNIS (Studi pada RM. Padang di Kota Malang)
}

\author{
Fauzan \\ Fakultas Ekonomi Universitas Kanjuruhan Malang \\ Email: gus_zain2001@yahoo.com
}

\begin{abstract}
Abstrak
Penelitian ini bertujuan menguji pengaruh religiusitas terhadap etika berbisnis pada bisnis rumah makan Padang di Kota Malang. Jenis penelitian adalah survei. Populasinya adalah para pemilik rumah makan Padang di Kota Malang. Teknik pengambilan sampelnya adalah simple random sampling. Penelitian ini menggunakan metode analisis regresi linear berganda. Hasil analisis menunjukkan bahwa semua variabel independen secara simultan berpengaruh positif dan signifikan terhadap variabel dependen. Secara parsial, dimensi ritual/syari'ah dan konsekuensi/akhlaq berpengaruh positif dan signifikan terhadap etika berbisnis. Dimensi ideologi/akidah berpengaruh negatif dan tidak signifikan terhadap etika berbisnis. Dimensi intelektual/ilmu berpengaruh positif dan tidak signifikan terhadap etika berbisnis. Dimensi religiusitas yang paling dominan mempengaruhi etika berbisnis adalah konsekuensial/akhlaq.
\end{abstract}

Kata kunci: Religiusitas, etika, etika berbisnis.

\begin{abstract}
The purpose of this research was to examine the influence of religiousity to ethics of business in the RM. Padang in Malang. This type of research was the survey. The population was the owners of RM. Padang in Malang and the sampling technique was simple random sampling. This research used multiple regression linear method. The result indicated that simultaneously all independent variables had a positive and significant effect to dependent variable. Partially, ritual/syari'ah and consequential/akhlaq dimension had a positive and significant effect to ethics of business. Ideology and Intelectual dimension did not have a positive and significant effect to ethic of business. The most dominant dimensions of religiousity that influenced business ethics was the consequential/akhlaq.
\end{abstract}

Keywords: Religiousity, ethics, business ethics.

\section{PENDAHULUAN}

Aktivitas bisnis saat ini tidak dapat dilepaskan dari aspek etika. Etika bisnis merupakan pemikiran atau refleksi tentang moralitas dalam ekonomi dan bisnis. Moralitas berarti aspek baik dan buruk, terpuji atau tercela, dan oleh karenanya diperbolehkan atau tidak dari perilaku manusia. Moralitas selalu berkaitan dengan apa yang dilakukan manusia dan kegiatan ekonomis merupakan suatu bidang perilaku manusia yang penting (Kartawiria, 2004).

Kegiatan ekonomi yang banyak melibatkan kalangan profesional seringkali dianggap sebagai pemicu rusaknya berbagai tatanan kehidupan dalam suatu masyarakat. Plato (427-347 SM) sebagaimana ditulis oleh Bertens mengemukakan bahwa letak ibu kota negara yang ideal adalah yang cukup jauh dari pantai laut agar tidak menjadi pusat bisnis. Ketika ibu kota suatu negara menjadi pusat bisnis, maka akan dipenuhi oleh para pebisnis. Para pebisnis akan menanamkan dalam jiwa manusia kebiasaan buruk untuk tidak setia dan menipu (Bertens, 2000). Kondisi tersebut dapat dihindari dengan mengembangkan kesadaran untuk menjaga moralitas dalam bisnis.

Pemahaman yang komprehensif mengenai etika dalam bisnis pada saat ini sangat penting. Gelombang reformasi 1997 membawa isu besar bahwa aspekaspek etis dalam hidup masyarakat dan bernegara sudah amat memprihatinkan (Ludigdo \& Maryani, 2001). Korupsi, kolusi, dan nepotisme merupakan masalah nasional yang memiliki konotasi etika yang kental. Aspek-aspek etis ini sebagian besar justru terkait dengan sektor ekonomi dan bisnis.

Perkembangan aktivitas ekonomi semakin cepat, termasuk dalam aktivitas usaha restoran, khususnya usaha rumah makan Padang. Rumah makan padang 
ada di setiap kota. Mereka memiliki konsep berdagang, rasa dan kualitas yang relatif hampir sama, baik untuk rumah makan yang berskala kecil maupun rumah makan yang berskala besar. Perbedaan antara rumah makan Padang yang satu dengan yang lainnya biasanya dalam kelengkapan dan ragam sajian yang dijual. Bisnis rumah makan Padang memiliki karakteristik tersendiri. Secara penyajian mereka memiliki konsep yang sama ialah mengutamakan "halal" dalam setiap sajiannya, sehingga rumah makan Padang menjadi tempat tujuan bagi orang-orang muslim. Mereka tidak perlu mengkhawatirkan masakan Padang yang tidak "halal".

Orang Minang sejatinya teguh memegang nilainilai agama (Islam). Nilai-nilai agama sudah diwariskan secara turun-temurun dengan filosofi bahwa orang Minangkabau berpedoman pada adat yang bersendikan syariat agama dan syariat agama bersendikan pada Kitab Allah (Alquran). Filosofi hidup tersebut membuat orang Minang memiliki praktik tersendiri dalam melakukan berbagai aktivitas, tidak terkecuali dalam aktivitas ekonominya. Salah satu aktivitas ekonomi orang Minang adalah bisnis rumah makan Padang.

Karakteristik dalam berbisnis yang dijalankan dengan muatan-muatan nilai agama, dengan mematuhi dan mentaati ajaran agamanya merupakan filosofi hidup pebisnis yang berasal dari Padang. Aktivitas ekonomi yang dijalankan berupa rumah makan Padang juga tidak terlepas dari filosofi hidupnya yang kental dengan ajaran-ajaran agama (Islam).

Analisis sosiologis perlu diungkapkan untuk mengenali dan mengidentifikasi kelompok-kelompok yang mempengaruhi konsekuensi atas tindakan moral serta yang mengarahkannya dalam memilih setiap tindakan etisnya (Cavanagh \& Bandsuch, 2002). Analisis ini penting dan perlu dilakukan karena kesadaran etis merupakan fenomena kelompok dan bukan hanya sekedar fenomena psikologi dan individual.

Memelihara standar etis yang tinggi di antara para pebisnis rumah makan Padang, tidak lain karena adanya integritas yang terjaga dan berlangsung secara kolektif dari ligkungan yang dihadapinya. Lingkungan (organisasi) dimana individu tersebut beraktivitas dapat mempengaruhi perilaku etis individu tersebut. Derajat keterpengaruhan juga tergantung pada kekuatan budaya pada lingkungan (organisasi) tersebut, dimana lingkungan memainkan peran yang signifikan dalam menentukan ekspresi nilai personal individu yang berada dalam lingkungan tersebut (Port, 2005).

Mencermati pemikiran etika yang ada, diharapkan adanya kerangka pemahaman yang lebih inklusif bahwa etika sebagai refleksi atau pemikiran atas moralitas mempunyai dimensi yang sangat luas. Pemikiran etika yang disampaikan oleh para ahli tersebut membentuk suatu gugusan-gugusan teori tentang etika. Mengambil simpul-simpul pemikiran yang ada, kesimpulan dari berbagai diskusi etika yang dapat dikedepankan adalah bagaimana manusia mencapai kebahagiaan dalam hidup dan kehidupannya. Berdasarkan uraian latar belakang permasalahan tersebut di atas, maka permasalahan yang akan diteliti dalam penelitian ini dapat dirumuskan sebagai berikut:

a. Apakah dimensi praktik agama (syari'ah/ritual) berpengaruh secara signifikan terhadap etika berbisnis pada RM. Padang di Kota Malang?

b. Apakah dimensi keyakinan (akidah/ideologi) berpengaruh secara signifikan terhadap etika berbisnis pada RM. Padang di Kota Malang?

c. Apakah dimensi pengetahuan (ilmu/intelektual) berpengaruh secara signifikan terhadap etika berbisnis pada RM. Padang di Kota Malang?

d. Apakah dimensi pengamalan (akhlaq/konsekuensial) berpengaruh secara signifikan terhadap etika berbisnis pada RM. Padang di Kota Malang?

e. Apakah religiusitas yang diproksikan dengan dimensi praktik agama (syari'ah/ritual), dimensi keyakinan (akidah/ideologi), dimensi pengetahuan (ilmu/intelektual), dan dimensi pengamalan (akhlaq/konsekuensial) secara bersama-sama (simultan) berpengaruh secara signifikan terhadap etika berbisnis pada RM. Padang di Kota Malang?

f. Dimensi manakah dari religiusitas yang paling berpengaruh secara dominan terhadap etika berbisnis pada RM. Padang di Kota Malang?

\section{LANDASAN TEORI DAN HIPOTESIS}

Istilah etika dalam bahasa Indonesia sebenarnya berasal dari bahasa Yunani: ethos, yang berarti kebiasaan atau watak. Etika juga berasal dari bahasa Perancis: etiquette atau dalam bahasa Indonesia dengan kata etiket yang berarti juga kebiasaan atau cara bergaul, berperilaku yang baik (Titus et al., 1984). Etika lebih merupakan pola perilaku atau kebiasaan yang baik dan dapat diterima oleh lingkungan pergaulan seseorang. Tergantung kepada situasi dan cara pandangnya, seseorang dapat menilai apakah etika yang digunakan itu bersifat baik atau buruk (Suseno, 1987).

Moralitas atau moral adalah istilah yang berasal dari bahasa Latin: mos (jamak: mores) yang berarti cara hidup atau kebiasaan. Moral atau morale dalam bahasa Inggris dapat diartikan sebagai semangat atau dorongan batin dalam diri seseorang untuk melaku- 
kan atau tidak melakukan sesuatu. Moralitas ini dilandasi oleh nilai-nilai tertentu yang diyakini oleh seseorang atau organisasi tertentu sebagai sesuatu yang baik atau buruk, sehingga bisa membedakan mana yang baik atau buruk (Muhni, 1994).

Perbedaan antara etika dan moralitas dapat dijelaskan sebagai suatu sistem nilai dalam diri seseorang atau suatu organisasi. Moralitas cenderung lebih merujuk kepada nilai-nilai yang diyakini dan menjadi semangat dalam diri seseorang untuk melakukan atau tidak melakukan sesuatu. Etika lebih merupakan nilai-nilai perilaku yang ditunjukkan oleh seseorang dalam interaksinya dengan lingkungan. Moralitas dapat melatarbelakangi etika seseorang.

Menurut Tjahjadi (1991), terdapat dua perbedaan antara etika, moral dan moralitas. Etika pada dasarnya merujuk kepada dua hal. Pertama, etika berkenaan dengan disiplin ilmu yang mempelajari tentang nilai-nilai yang dianut oleh manusia beserta pembenarannya dan dalam hal ini etika merupakan salah satu cabang filsafat. Kedua, etika merupakan pokok permasalahan dalam disiplin ilmu itu sendiri yaitu nilai-nilai hidup dan hukum-hukum yang mengatur tingkah laku manusia.

Moral dalam pengertian umum menekankan pada karakter atau sifat-sifat individu yang khusus, di luar ketaatan kepada peraturan. Oleh karena itu, moral merujuk kepada tingkah laku yang bersifat spontan seperti rasa kasih, kemurahan hati, kebesaran jiwa, dan sebagainya. Moralitas mempunyai makna yang lebih khusus sebagai bagian dari etika. Moralitas berfokus pada hukum-hukum dan prinsip-prinsip yang abstrak dan bebas. Perbuatan yang sesuai dengan moralitas tidak sepenuhnya bermoral dan melakukan hal benar dengan alasan-alasan yang salah bisa berarti tidak bermoral sama sekali (Tjahjadi, 1991).

Conroy \& Emerson (2002) mengemukakan bahwa etika secara konseptual memiliki kecenderungan dipandang sebagai suatu sistem nilai apa yang baik dan buruk bagi manusia dan masyarakat. Batasanbatasan nilai normatif dalam interaksi dengan masyarakat dan lingkungannya itulah yang kemudian dapat dikatakan sebagai nilai-nilai etika. Nilai-nilai dalam diri seseorang yang akan mengendalikan dimunculkan atau tidaknya kepatuhan terhadap nilainilai etika dapat disebut dengan moral atau moralitas (Tjahjadi, 1991).

Suseno (1987) mengemukakan prinsip-prinsip etika diantaranya adalah sebagai berikut:

a. Prinsip keindahan (beauty). Prinsip ini mendasari segala sesuatu yang mencakup penikmatan rasa senang terhadap keindahan.

b. Prinsip persamaan (equality). Hakekat kemanusia- an menghendaki adanya persamaan antara manusia yang satu dengan manusia yang lain. Setiap manusia yang lahir memiliki hak dan kewajiban masing-masing yang pada dasarnya adalah sama atau sederajat. Etika yang dilandasi oleh prinsip persamaan ini dapat menghilangkan perilaku diskriminatif (yang membeda-bedakan) dalam berbagai aspek interaksi manusia.

c. Prinsip kebaikan (goodness). Prinsip kebaikan sangat erat kaitannya dengan hasrat dan cita-cita manusia. Apabila orang menginginkan kebaikan dari suatu ilmu pengetahuan, maka akan mengandalkan pada obyektivitas ilmiah, kemanfaatan pengetahuan, rasionalitas, dan sebagainya.

d. Prinsip keadilan (justice). Definisi tertua yang hingga kini masih sangat relevan untuk merumuskan keadilan adalah justice. Justice berasal dari zaman Romawi Kuno, "justitia est contants et perpetua voluntas jus suum cuique tribunendi" (Keadilan adalah kemauan yang tetap dan kekal untuk memberikan kepada setiap orang apa yang semestinya).

e. Prisip kebebasan (liberty). Kebebasan dapat dirumuskan sebagai keleluasaan untuk bertindak atau tidak bertindak berdasarkan pilihan yang tersedia bagi seseorang. Kebebasan muncul dari dokrtin bahwa setiap orang memiliki hidupnya sendiri serta memiliki hak untuk bertindak sendiri kecuali jika pilihan tindakan tersebut melanggar kebebasan yang sama dari orang lain. Kebebasan manusia mengandung pengertian: (1) Kemampuan untuk menentukan diri sendiri, (2) Kesanggupan untuk mempertanggungjawabkan perbuatan, (3) Syarat-syarat yang memungkinkan manusia untuk melaksanakan pilihan-pilihannya beserta konsekuensi dari pilihan itu. Tidak ada kebebasan tanpa tanggung jawab dan tidak ada tanggung jawab tanpa kebebasan, semakin besar kebebasan yang dimiliki semakin besar pula tanggung jawab yang dipikul.

f. Prinsip kebenaran (truth). Ide kebenaran biasanya dipakai dalam pembicaraan mengenai logika ilmiah. Kebenaran mutlak dapat dibuktikan dengan keyakinan, bukan dengan fakta yang ditelaah oleh teologi dan ilmu agama. Kebenaran harus dapat dibuktikan dan ditunjukkan kepada masyarakat agar masyarakat merasa yakin akan kebenaran itu. Perlu ada penghubung antara kebenaran dalam pemikiran (truth in the mind) dengan kenyataan (truth in reality) atau kebenaran yang terbuktikan.

Setiap manusia memiliki naluri religiusitas, yaitu naluri untuk berkepercayaan. Naluri itu muncul 
bersamaan dengan hasrat memperoleh kejelasan tentang hidup dan alam raya yang menjadi lingkungan hidup sendiri. Keberagamaan atau religiusitas diwujudkan dalam berbagai sisi kehidupan manusia. Aktivitas beragama bukan hanya terjadi ketika seseorang melakukan perilaku ritual (beribadah), tetapi juga ketika melakukan aktivitas lain yang didorong oleh kekuatan supra natural.

Menurut Suhardiyanto (2001), religiusitas adalah hubungan pribadi dengan pribadi ilahi Yang Maha Kuasa, Maha Pengasih dan Maha Penyayang (Tuhan) yang berkonsekuensi hasrat untuk berkenan kepada pribadi yang ilahi itu dengan melaksanakan kehendak-Nya dan menjauhi yang tidak dikehendakinya (larangannya). Hubungan pribadi yang baik dengan pribadi yang ilahi ini menurut Suhardiyanto (2001) memampukan orang untuk melihat kebaikan Tuhan dalam sesama, suatu sikap yang setelah tumbuh dan berkembang dalam diri seseorang akan membuahkan cinta tidak hanya pada Tuhan saja tetapi juga pada sesama ciptaan Tuhan, baik itu manusia maupun alam ciptaan lain sehingga dalam hidup sehari-hari sebagai buahnya bagi manusia akan tumbuh atau muncul sikap saling menghargai, saling mencintai, dan muncul rasa sayang pada alam lingkungannya, sehingga "kesejahteraan bersama, lahir batin" dapat terwujud.

Menurut Glock \& Stark (1994) seperti ditulis oleh Ancok (1994), konsep religiusitas adalah rumusan brilian. Konsep tersebut melihat keberagamaan seseorang bukan hanya dari satu atau dua dimensi, tetapi memperhatikan segala dimensi. Keberagamaan dalam Islam bukan hanya diwujudkan dalam bentuk ibadah ritual saja, tetapi juga dalam aktivitas-aktivitas lainnya. Sebagai suatu sistem yang menyeluruh, Islam mendorong pemeluknya untuk beragama secara menyeluruh. Ada lima dimensi keberagamaan seseorang yang dapat diukur untuk mengetahui apakah seseorang tersebut religius atau tidak, yaitu dimensi keyakinan, dimensi praktek agama (ritual dan ketaatan), dimensi pengalaman, dimensi pengetahuan agama, dimensi pengamalan atau konsekuensi. (Ancok, 1994)

Penjelasan kelima dimensi religiusitas ini seperti yang ditulis oleh Ancok (1994) adalah sebagai berikut: Pertama, dimensi keyakinan, yang berisi pengharapan-pengharapan dimana orang religius berpegang teguh pada pandangan teologis tertentu dan mengakui kebenaran doktrin-doktrin tersebut. Kedua, dimensi praktik agama, dimensi ini mencakup perilaku pemujaan, ketaatan dan hal-hal yang dilakukan orang untuk menunjukkan komitmen terhadap agama yang dianutnya. Dimensi praktik agama ini terdiri atas dua hal penting, yaitu, ritual yang mengacu pada semangat ritus, tindakan keagamaan formal dan praktek-praktek suci yang semua mengharapkan para pemeluk melaksanakan. Ketaatan mengacu pada kemauan para pemeluk untuk melaksanakan segala aturan yang diperintahkan oleh agamanya dan meninggalkan segala sesuatu yang dilarang oleh ajaran agamanya. Ketiga, dimensi pengalaman, berisikan dan memperhatikan fakta bahwa semua agama mengandung pengharapanpengharapan tertentu, meski tidak tepat jika dikatakan bahwa seseorang yang beragama dengan baik pada suatu waktu akan mencapai pengetahuan subjektif dan langsung mengenai kenyataan terakhir. Dimensi ini berkaitan dengan pengalaman keagamaan, perasaan-perasaan, persepsi-persepsi, dan sensasisensasi yang dialami seseorang atau didefinisikan oleh suatu kelompok keagamaan yang melihat komunikasi, walaupun kecil, dalam suatu esensi ketuhanan, yaitu dengan Tuhan, kenyataan terakhir, dengan otoritas transedental. Keempat, dimensi pengetahuan agama. Dimensi ini mengacu kepada harapan bahwa orang-orang yang beragama paling tidak memiliki sejumlah minimal pengetahuan mengenai dasar-dasar keyakinan, ritus-ritus, kitab suci dan tradisi-tradisi. Kelima, dimensi pengamalan atau konsekuensi. Dimensi ini mengacu pada identifikasi akibat-akibat keyakinan keagamaan, praktik, pengalaman, dan pengetahuan seseorang dari hari ke hari.

Menurut konsep religiusitas versi Glock \& Stark (1994), dimensi keyakinan (ideological) dapat disejajarkan dengan akidah, yang menunjuk pada seberapa tingkat keyakinan Muslim terhadap ajaran agamanya, terutama terhadap ajaran-ajaran yang bersifat fundamental dan dogmatik. Praktik agama (ritual) disejajarkan dengan syari'ah, yang menunjukkan seberapa tingkat kepatuhan Muslim dalam mengerjakan kegiatan-kegiatan ritual sebagaimana dianjurkan oleh agamanya. Dimensi pengamalan (konsekuensial) disejajarkan dengan akhlaq, yang menunjuk pada seberapa tingkatan Muslim berperilaku dimotivasi oleh ajaran-ajaran agamanya, yaitu bagaimana individu berelasi dengan dunianya, terutama dengan manusia lain. Dimensi pengetahuan (ilmu) menunjuk pada seberapa tingkat pengetahuan dan pemahaman Muslim terhadap ajaran agamanya, terutama mengenai ajaran-ajaran pokok dari agamanya, sebagaimana termuat dalam kitab sucinya. Dimensi pengalaman atau penghayatan (experiential) menunjuk pada seberapa jauh seorang Muslim dalam merasakan dan mengalami perasaan-perasaan dan pengalaman religius (Ancok, 1994).

Penelitian mengenai etika dalam bisnis dewasa ini sudah sedemikian berkembang. Perkembangan ini terjadi baik pada persoalan yang diteliti maupun 
pendekatan yang digunakan untuk meneliti. Pendekatan penelitian yang digunakan, khususnya di luar negeri (Amerika Serikat, Kanada, Inggris, dan Australia), baik pendekatan kuantitatif (positivistic) maupun kualitatif (non-positivistic) telah sama-sama dilakukan. Pendekatan penelitian tentang etika dalam bisnis di Indonesia masih banyak dilakukan dengan pendekatan positivistic (Ludigdo, 2005).

Penelitian yang telah dilakukan maupun yang akan dilakukan merupakan suatu usaha bahwa isu etika bisnis merupakan bidang garapan intelektual dan akademis yang tidak kalah pentingnya dengan bidang lain. Peranan etika bisnis tidak boleh hanya bersifat sementara, karena menyangkut suatu aspek hakiki dari bisnis. Aktivitas bisnis serta semua pihak yang terlibat di dalamnya akan dirugikan bila segi etika ini diabaikan (Bertens, 2000).

Ludigdo \&Maryani (2001) dalam hasil surveynya mendeskripsikan secara parsial faktor-faktor yang mempengaruhi sikap dan perilaku etis akuntan, ditemukan sikap dan perilaku etis akuntan tersebut ternyata dipengaruhi oleh berbagai faktor. Faktorfaktor tersebut yang dominan adalah keberagamaan, pendidikan, dan organisasional.

Peneliti lain yang mendekati dengan pendekatan non-positivistik diantaranya adalah Lovell (2002) yang melakukan interview langsung kepada partisipannya untuk menjelaskan dependensi variabel etika dalam pengambilan keputusan organisasional dan individual. Weaver \& Agle (2002) melakukan studi literatur dengan mendasarkan pada perspektif interaksionisme simbolik. Dalam studi ini mereka mendiskusikan hubungan antara keberagamaan (religiousity) dengan perilaku etis dalam organisasi.

Berdasarkan pada teori dan temuan empiris tersebut, maka dikembangkan hipotesis penelitian sebagai berikut:

H1: Dimensi praktik agama (ritual/syari'ah) berpengaruh positif terhadap etika berbisnis pada RM. Padang di Kota Malang
H2: Dimensi keyakinan (ideologi/akidah) berpengaruh positif terhadap etika berbisnis pada RM. Padang di Kota Malang

H3: Dimensi pengetahuan (intelektual/1mu) berpengaruh positif terhadap etika berbisnis pada RM. Padang di Kota Malang

H4: Dimensi pengamalan (konsekuensial/akhlaq) berpengaruh positif terhadap etika berbisnis pada RM. Padang di Kota Malang

\section{METODE PENELITIAN}

Penelitian ini merupakan penelitian penjelasan (explanatory research) yang akan membuktikan hubungan kausal antara variabel bebas (independent variable), yaitu variabel religiusitas yang diproksikan dengan ritual/syari'ah, ideologi/akidah, intelektual/ ilmu, dan konsekuensial/akhlaq, dan variabel terikat (dependent variable), yaitu etika berbisnis. Jenis penelitian ini dipilih agar dapat dibangun suatu hasil analisis yang dapat berfungsi untuk menjelaskan, meramalkan, dan mengontrol suatu gejala atau hubungan antar variabel bebas dengan variabel terikat (Arikunto, 2002).

Populasi dalam penelitian ini adalah para pemilik atau pengusaha RM. Padang di Kota Malang yang jumlahnya 89 orang. Lokasi penelitian ini dilakukan pada RM. Padang di Kota Malang dengan alasan: pertama, RM. Padang merupakan bisnis kuliner yang memiliki karakteristik tersendiri. Kedua, Bisnis RM. Padang di Kota Malang memiliki jumlah yang paling banyak diantara bisnis sejenis. Ketiga, RM. Padang memiliki tingkat pertumbuhan yang pesat.

Penelitian ini menarik sampel dengan menggunakan metode atau teknik simple random sampling, dimana jumlah sampel ditentukan dengan menggunakan rumus dari Taro Yamane dalam Sugiyono (2005), yaitu $\mathrm{n}=\mathrm{N}:\left(\left(\mathrm{N} \mathrm{x} \mathrm{d}^{2}\right)+1\right)$, dimana $\mathrm{n}$ adalah jumlah sampel, $\mathrm{N}$ adalah jumlah populasi, dan $\mathrm{d}^{2}$

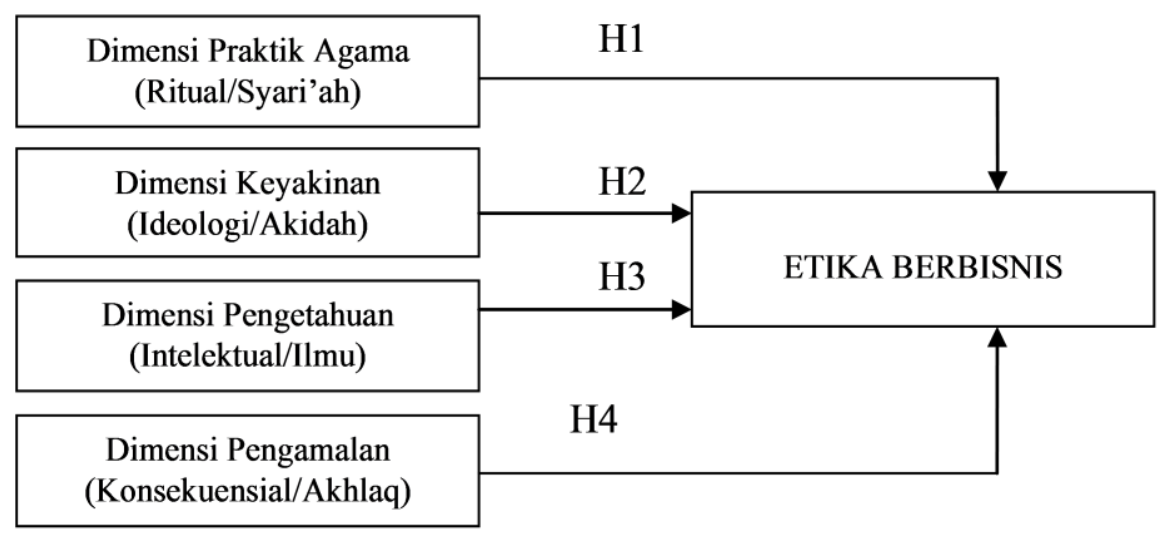

Gambar 1. Kerangka Konsep Penelitian 
adalah tingkat presisi atau akurasi yang ditetapkan $(=10 \%)$, sehingga besarnya sampel adalah sebanyak 47 pebisnis RM. Padang.

\section{Definisi Operasional dan Pengukuran Variabel}

Religiusitas (X) diartikan sebagai rasa berkepercayaan seseorang dalam meyakini ajaran agamanya, mengimplementasikan keimanannya dalam kehidupan sehari-harinya dan bagaimana hubungannya dengan sang Khaliknya (Ancok, 1994). Dimensi religiusitas meliputi:

a. Dimensi praktik agama-syari'ah/ritual (X1). Dimensi ini menunjuk pada seberapa besar tingkat kepatuhan muslim dalam mengerjakan kegiatankegiatan ritual sebagaimana diperintahkan oleh agamanya, adapun isinya: pelaksanaan sholat, puasa, zakat, haji, membaca Al-qur'an, berdoa dan berdzikir, ibadah qurban, dan i'tikaf di masjid

b. Dimensi keyakinan-akidah/ideologi (X2). Dimensi ini menunjuk pada seberapa besar tingkat keyakinan muslim terhadap kebenaran ajaranajaran agamanya, terutama terhadap ajaran-ajaran yang bersifat fundamental dan dogmatik, adapun isinya: keimanan menyangkut keyakinan tentang Allah, para malaikat Allah, nabi dan rosul Allah, kitab-kitab Allah, surga dan neraka, qadha dan qodhar.

c. Dimensi pengetahuan agama-ilmu/intelektual (X3). Dimensi ini menunjuk pada seberapa besar tingkat pengetahuan dan pemahaman muslim terhadap ajaran-ajaran agamanya, terutama mengenai ajaran pokok dari agamanya, sebagaimana termuat dalam kitab sucinya, adapun isinya: pengetahuan tentang isi Al-qur'an, pokok-pokok ajaran yang harus diimani dan dilaksanakan (rukun Islam dan rukun Iman), hukum-hukum Islam, sejarah Islam

d. Dimensi pengamalan-akhlaq/konsekuensial (X4). Dimensi ini menunjuk pada seberapa besar tingkatan muslim berperilaku yang dimotivasi oleh agamanya, yaitu bagaimana individu berelasi dengan dunianya, terutama dengan manusia lain, adapun isinya: perilaku suka menolong, bekerja sama, berderma, menyejahterakan dan menumbuh kembangkan orang lain, menegakkan keadilan dan kebenaran, berlaku jujur, suka memaafkan, menjaga lingkungan hidup, menjaga amanah, dan tidak menipu

Etika berbisnis $(\mathrm{Y})$ diartikan sebagai nilai-nilai dan norma-norma moral yang menjadi pegangan bagi seseorang atau suatu kelompok dalam mengatur tingkah lakunya (Bertens, 2000). Etika berbisnis diukur dengan: a. Kejujuran. Prinsip kejujuran akan melahirkan berbagai sikap yang terpuji, yaitu: tidak menutupi cacat barang yang di jual, tidak melakukan penipuan dalam jual beli, tidak melakukan gharar (transaksi fiktif) dalam jual beli, tidak mengambil riba dan tidak melakukan perbuatan sumpah agar barang yang dijual laku.

b. Keadilan. Prinsip keadilan mencakup pada keseimbangan dan tanggung jawab. Keseimbangan di dunia dan di akhirat serta tanggung jawab kepada sesama manusia dan tanggung jawab kepada Allah atas segala yang telah diperbuatnya di dunia.

Data yang diambil dalam penelitian ini adalah berupa data primer, sedangkan metode pengumpulan data dilakukan dengan kuisioner yang diberikan kepada responden secara langsung (Sugiyono, 2005). Teknik analisis data merupakan alat yang dipergunakan dalam memecahkan masalah. Penelitian ini menggunakan metode analisis regresi linear berganda dan pengujian hipotesis dilakukan dengan menggunakan uji t, uji $F$, dan uji $\mathrm{R}^{2}$. Analisis regresi digunakan untuk mengetahui bagaimana kuatnya pengaruh beberapa variabel independen terhadap variabel dependen, yaitu religiusitas terhadap etika berbisnis pada RM. Padang di Kota Malang.

\section{HASIL PENELITIAN DAN PEMBAHASAN}

Uji validitas dilakukan untuk melihat valid tidaknya masing-masing instrumen yang digunakan dalam variabel penelitian. Sesuai dengan hasil analisis data primer, maka masing-masing instrumen yang digunakan dalam penelitian memiliki hasil uji yang menunjukkan bahwa nilai Sig. correlation $<\alpha(5 \%)$ dan $t_{\text {hitung }}>t_{\text {tabel }}(0,279)$. Hasil analisis semua $t_{\text {hitung }}>t$ tabel yang artinya bahwa semua variabel yang digunakan dalam instrumen penelitian adalah valid (Ghozali, 2005).

Uji reliabilitas instrumen penelitian mempertimbangkan besarnya koefesien reliabilitas. Sesuai dengan hasil analisis data primer, maka masingmasing instrumen yang digunakan dalam penelitian memiliki hasil uji yang menunjukkan bahwa angka cronbach alpha diatas 0,6 (Ghozali, 2005), artinya dari uji reliabilitas dapat dikatakan bahwa seluruh variabel yang digunakan dalam penelitian ini adalah reliabel.

\section{Hasil Uji Asumsi Klasik}

Tujuan penggunaan uji asumsi klasik adalah agar diperoleh estimator tidak bias dari regresi dengan kuadrat terkecil biasa. Model regresi yang baik adalah jika tidak terjadi hubungan antar variabel independen. 
Kriteria pengukurannya adalah jika nilai toleransi $\leq 1$ berarti tidak ada korelasi antar variabel independen dan jika VIF tidak melebihi 10, maka model dinyatakan tidak terkena persoalan multikolinier (Ghozali, 2005). Ikhtisar uji multikolinieritas sebagaimana output SPSS dapat dilihat pada Tabel 1. Hasil uji multikolinieritas menunjukkan empat variabel bebas tidak mengalami multikolinieritas.

\section{Tabel 1. Interpretasi Uji Multikolinieritas}

\begin{tabular}{clccc}
\hline No $\quad$ Variabel & \multicolumn{2}{c}{ Tolerance } & VIF & Keputusan \\
\hline 1 & Ritual (X1) & 0,714 & $\begin{array}{c}1,400 \\
\text { Tidak terjadi } \\
\text { multikol }\end{array}$ \\
2 & Ideologi (X2) & 0,488 & $\begin{array}{c}2,047 \text { Tidak terjadi } \\
\text { multikol }\end{array}$ \\
3 & Intelektual (X3) & 0,701 & $\begin{array}{c}1,426 \text { Tidak terjadi } \\
\text { multikol }\end{array}$ \\
4 & Konsekuensial (X4) & 0,599 & $\begin{array}{c}1,668 \text { Tidak terjadi } \\
\text { multikol }\end{array}$ \\
\hline
\end{tabular}

Sumber: Data Diolah 2012

Uji heteroskedastisitas dilakukan dengan menggunakan grafik scatter plot, jika titik-titik menyebar secara acak dan tidak membentuk suatu pola tertentu yang jelas, serta tersebar baik di atas maupun di bawah angka 0 pada sumbu Y, hal ini berarti tidak terjadi heteroskedastisitas atau data homogen (Ghozali, 2005). Gambar scatter plot uji heteroskedastisitas dapat dilihat pada Gambar 2.
Pada grafik scatter plot hasil output SPSS terlihat titik-titik menyebar secara acak dan tidak membentuk suatu pola tertentu yang jelas, serta tersebar baik di atas maupun di bawah angka 0 pada sumbu $Y$, hal ini berarti data telah memenuhi asumsi homogenitas atau tidak terjadi heteroskedastisitas.

Model regresi yang baik adalah jika semua variabel berdistribusi normal. Jika data menyebar di sekitar garis diagonal dan mengikuti arah garis diagonal, maka model regresi memenuhi asumsi normalitas (Ghozali, 2005). Gambar normal probability plot uji Normalitas dapat dilihat pada Gambar 3.

Berdasarkan grafik normal probability plot uji normalitas output SPSS di atas, diketahui bahwa sebaran data yang ada menyebar di sekitar garis diagonal dan mengikuti arah garis diagonal, dengan demikian dapat disimpulkan bahwa data mempunyai distribusi normal.

Pengujian statistik dengan alat analisis regresi linier berganda dimaksudkan untuk mengetahui pengaruh ritual/syari'ah $\left(\mathrm{X}_{1}\right)$, ideologi/akidah $\left(\mathrm{X}_{2}\right)$, intelektual/ilmu $\left(\mathrm{X}_{3}\right)$, dan konsekuensial/akhlaq $\left(\mathrm{X}_{4}\right)$ terhadap etika berbisnis RM. Padang di Kota Malang. Ikhtisar output uji regresi liniear berganda dapat dilihat pada Tabel 2.

Persamaan regresi linier berganda sebagaimana pada ikhtisar output SPSS adalah:

$\mathrm{Y}=1,004+0,316 \mathrm{X}_{1}+-0,110 \mathrm{X}_{2}+0,150 \mathrm{X}_{3}+$ $0,415 X_{4}+0,753$

\section{Scatterplot}

Dependent Variable: ETIKA BISNIS

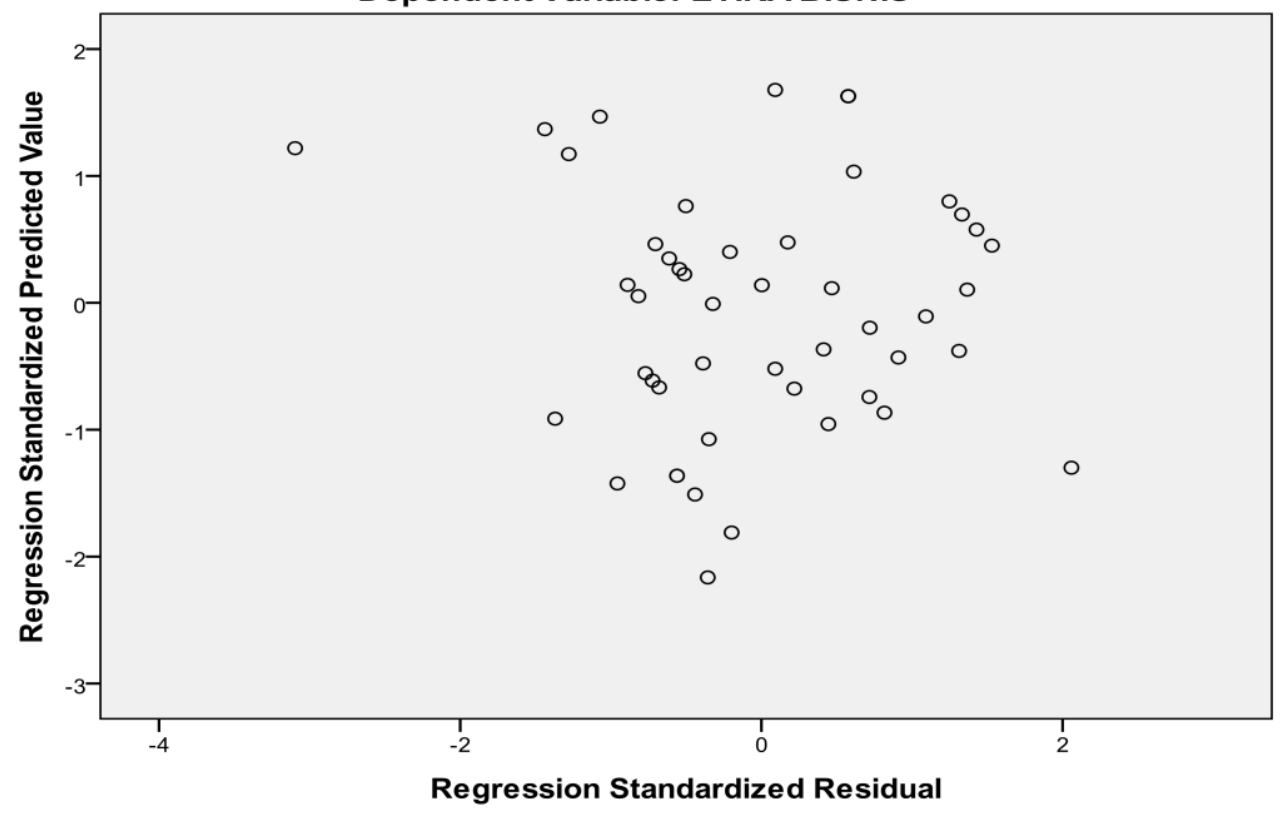

Gambar 2. Scatter Plot Uji Heteroskedastisitas 


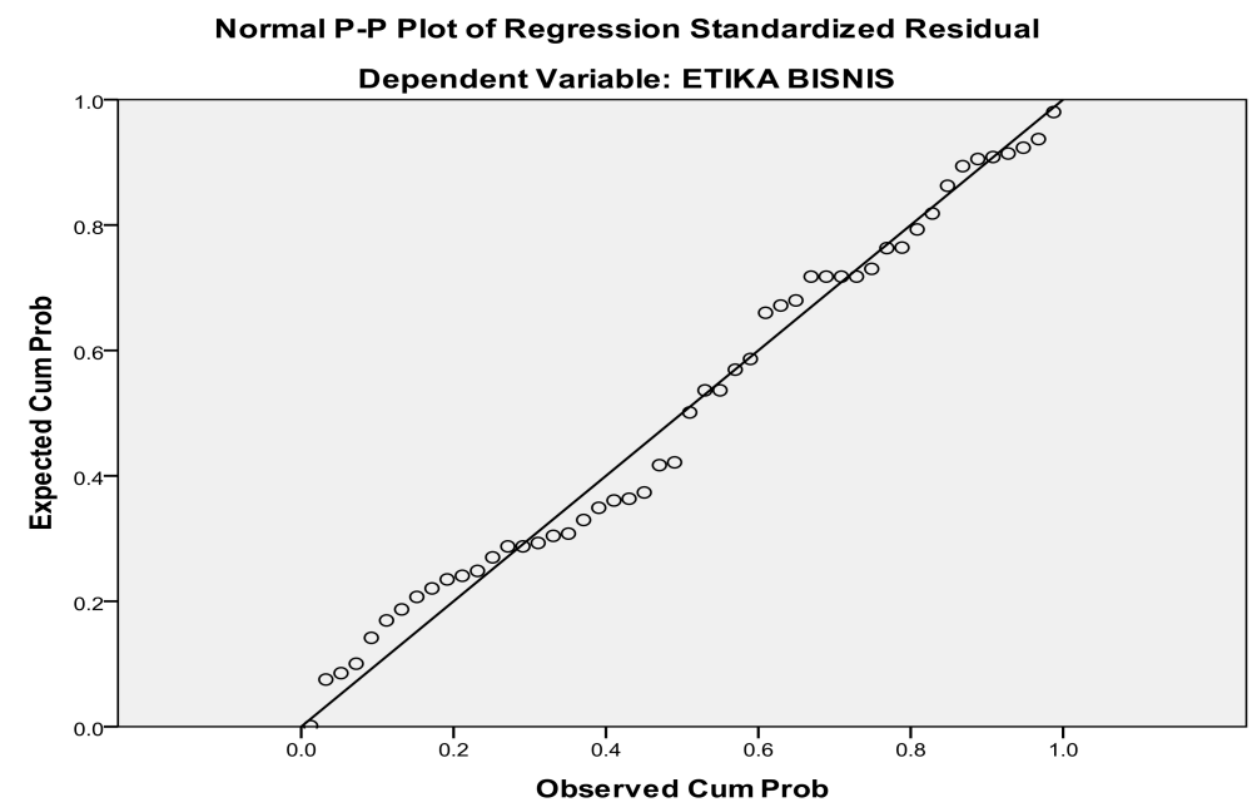

Gambar 3. Normal P-P Plot Uji Normalitas

Tabel 2. Ikhtisar Output Regresi Linier Berganda

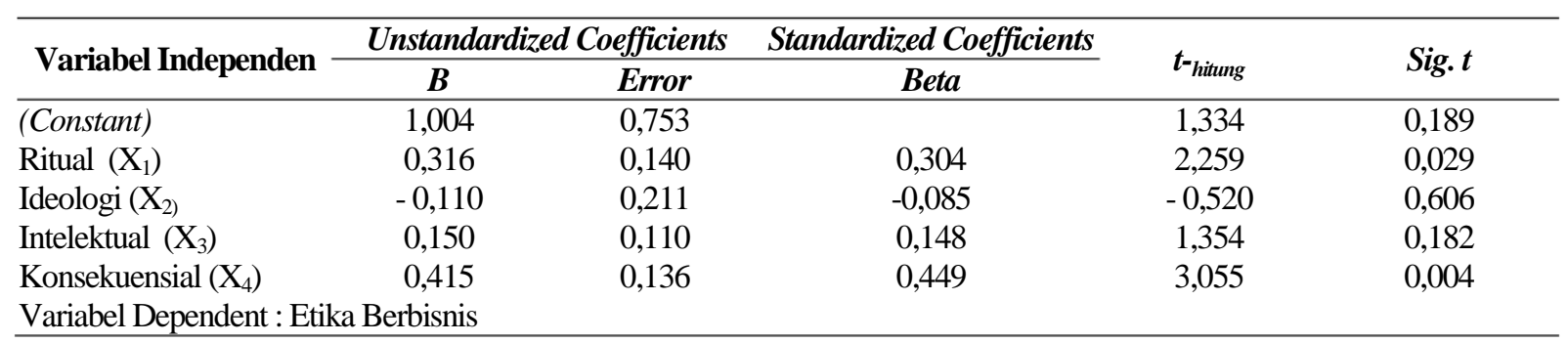

Sumber: Data Diolah 2012

Persamaan tersebut menunjukkan hal-hal sebagai berikut:

(1) Nilai koefisien konstanta adalah sebesar 1,004. Hal ini berarti bahwa apabila nilai koefisien ritual $\left(\mathrm{X}_{1}\right)$, ideologi $\left(\mathrm{X}_{2}\right)$, intelektual $\left(\mathrm{X}_{3}\right)$, dan konsekuensial $\left(\mathrm{X}_{4}\right)$ sebesar 0 (nol), maka etika berbisnis akan naik sebesar 1,004.

(2) Variabel ritual $\left(X_{1}\right)$ memiliki nilai koefisien sebesar 0,316. Hal ini menunjukkan bahwa setiap satuan variabel ritual akan berpengaruh terhadap etika berbisnis RM. Padang sebesar 0,316 apabila variabel lainnya tetap.

(3) Variabel ideologi $\left(X_{2}\right)$ memiliki nilai koefisien sebesar -0,110. Hal ini menunjukkan bahwa setiap satuan variabel ideologi akan berpengaruh terhadap perilaku etika berbisnis sebesar $-0,110$ apabila variabel lainnya tetap. Nilai koefisien variabel ideologi bernilai negatif, artinya ideologi memiliki pengaruh yang berlawanan terhadap etika berbisnis seseorang. Hal ini tidak dapat dilepaskan dari sudut pandang seseorang dalam beraktivitas di segala bidang kehidupan.
(4) Variabel intelektual $\left(X_{3}\right)$ memiliki nilai koefisien sebesar 0,150. Hal ini menunjukkan bahwa setiap satuan variabel intelektual akan berpengaruh terhadap etika berbisnis RM. Padang sebesar 0,150 apabila variabel lainnya tetap.

(5) Variabel konsekuensial $\left(\mathrm{X}_{4}\right)$ memiliki nilai koefisien sebesar 0,415. Hal ini menunjukkan bahwa setiap satuan variabel konsekuensial akan berpengaruh terhadap etika berbisnis RM. Padang sebesar 0,415 apabila variabel lainnya tetap.

Besar kecilnya koefesien determinasi atau $\mathrm{R}^{2}$ digunakan untuk menyatakan kecocokan model regresi. Besarnya koefisien determinasi dapat dilihat pada Tabel 3. Dari tabel tersebut terlihat bahwa koefisien $\mathrm{R}^{2}$ hitung (koefisien determinasi) adalah sebesar 0,417, artinya dapat disimpulkan bahwa kemampuan variabel religiusitas yang diproksikan dengan ritual, ideologi, intelektual, dan konsekuensi untuk menjelaskan variasi pada variabel etika berbisnis adalah sebesar 41,7\%, sedangkan sisanya 
sebesar 58,3\% etika berbisnis pada RM. Padang di Kota Malang dipengaruhi oleh faktor lain yang tidak dijelaskan dalam model regresi tersebut.

Tabel 3. Ikhtisar Output Koefesien Determinasi

\begin{tabular}{ccccc}
\hline $\mathbf{R}$ & $\begin{array}{c}\mathbf{R} \text { Square } \\
\left(\mathbf{R}^{\mathbf{2}}\right)\end{array}$ & $\begin{array}{c}\text { Adjusted } \\
\mathbf{R} \text { Square }\end{array}$ & F-hitung & Sig. F \\
\hline 0,646 & 0,417 & 0,365 & 8,038 & 0,000 \\
\hline
\end{tabular}

Sumber: Data diolah 2012

Uji t digunakan untuk menguji kebenaran hipotesis penelitian. Pengujian dilakukan dengan alat penguji signifikansi t-test. Kriteria yang digunakan untuk menyatakan apakah koefisien korelasi parsial yang diperoleh signifikan atau tidak signifikan adalah milai koefisien t. Uji t merupakan uji signifikansi untuk mengukur keberartian koefisien regresi variabel independen satu per satu. Nilai koefisien $t$ harus dibandingkan dengan harga $t_{\text {tabel }}$ untuk alpha yang ditetapkan dengan $\mathrm{dk}$ yang sesuai, untuk $\mathrm{dk}(\mathrm{n}-\mathrm{k}-1)=$ $\mathrm{dk}(50-4-1)=\mathrm{dk}(45)$ dengan alpha 5\% adalah sebesar 1,679. Kriteria yang digunakan, yaitu menolak $\mathrm{H}_{0}$ dan menerima $\mathrm{H}_{\mathrm{a}}$ apabila $\mathrm{t}_{\text {hitung }}>\mathrm{t}_{\text {tabel }}$ serta menerima $\mathrm{H}_{0}$ dan menolak $\mathrm{H}_{\mathrm{a}}$ apabila $\mathrm{t}_{\text {hitung }}<$ $\mathrm{t}_{\text {tabel, }}$, atau melihat dari harga probabilitas hitung dibandingkan dengan level of significance $(\alpha)$ yang sudah ditetapkan yaitu $(0,05)$. Kriteria yang digunakan, yaitu menolak $\mathrm{H}_{0}$ dan menerima $\mathrm{H}_{\mathrm{a}}$ apabila probabilitas hitung $<$ level of significance $(\alpha)$ serta menerima $\mathrm{H}_{0}$ dan menolak $\mathrm{H}_{\mathrm{a}}$ apabila probabilitas hitung $>$ level of significance $(\alpha)$.

(1) Uji signifikan t-test antara ritual $\left(\mathrm{X}_{1}\right)$ terhadap etika berbisnis (Y).

Dari hasil analisis diperoleh nilai $\mathrm{t}_{\text {hitung }}$ ritual $\left(\mathrm{X}_{1}\right)$ sebesar 2,259 pada tingkat probabilitas 0,029. Hasil pengujian menunjukkan bahwa nilai probabilitas hitung 0,029<0,05 atau probabilitas hitung < level of significance $(\alpha)$, sehingga $\mathrm{H}_{0}$ ditolak. Hal ini berarti bahwa ritual $\left(\mathrm{X}_{1}\right)$ berpengaruh positif dan signifikan terhadap etika berbisnis (Y) RM. Padang di Kota Malang diterima.

(2) Uji signifikan t-test antara ideologi $\left(\mathrm{X}_{2}\right)$ terhadap etika berbisnis (Y).

Dari hasil analisis diperoleh $t_{\text {hitung }}$ ideologi $\left(\mathrm{X}_{2}\right)$ sebesar $-0,520$ pada tingkat probabilitas 0,606 . Hasil pengujian menunjukkan bahwa nilai probabilitas hitung 0,606 $>0,05$ atau probabilitas hitung > level of significance $(\alpha)$, sehingga $\mathrm{H}_{0}$ diterima. Hal ini berarti bahwa ideologi $\left(\mathrm{X}_{2}\right)$ tidak berpengaruh negatif dan signifikan terhadap etika berbisnis (Y) RM. Padang di Kota Malang diterima.
(3) Uji signifikan t-test antara intelektual $\left(X_{3}\right)$ terhadap etika berbisnis (Y).

Dari hasil analisis diperoleh $\mathrm{t}_{\text {hitung }}$ intelektual $\left(\mathrm{X}_{3}\right)$ sebesar 1,354 pada tingkat probabilitas 0,182. Hasil pengujian menunjukkan bahwa nilai prbabilitas hitung 0,182>0,05 atau probabilitas hitung > level of significance $(\alpha)$, sehingga $\mathrm{H}_{0}$ diterima. Hal ini berarti bahwa intelektual $\left(\mathrm{X}_{3}\right)$ tidak berpengaruh positif dan signifikan terhadap etika berbisnis (Y) RM. Padang di Kota Malang diterima.

(4) Uji signifikan t-test antara konsekuensial $\left(\mathrm{X}_{4}\right)$ terhadap etika berbisnis (Y).

Dari hasil analisis diperoleh nilai $t_{\text {hitung }}$ konsekuensial $\left(\mathrm{X}_{4}\right)$ sebesar 3,055 pada tingkat probabilitas 0,004. Hasil pengujian menunjukkan bahwa nilai probabilitas hitung $0,004<0,05$ atau probabilitas hitung < level of significance $(\alpha)$, sehingga $\mathrm{H}_{0}$ ditolak. Hal ini berarti bahwa konsekuensial $\left(\mathrm{X}_{4}\right)$ berpengaruh positif dan signifikan terhadap etika berbisnis (Y) RM. Padang di Kota Malang diterima.

Uji $\mathrm{F}$ digunakan untuk mengetahui pengaruh secara simultan variabel ritual $\left(\mathrm{X}_{1}\right)$, ideologi $\left(\mathrm{X}_{2}\right)$, intelektual $\left(\mathrm{X}_{3}\right)$, dan konsekuensial $\left(\mathrm{X}_{4}\right)$, terhadap etika berbisnis (Y). Berdasarkan output SPSS diperoleh nilai $\mathrm{F}_{\text {hitung }}=8,038$ dengan probabilitas 0,000 . Kriteria pengujian menyatakan jika probabilitas hitung < level of significance $(\alpha)$, maka $\mathrm{H}_{0}$ ditolak atau ada pengaruh positif dan signifikan secara simultan religiusitas yang diproksikan dengan ritual $\left(\mathrm{X}_{1}\right)$, ideologi $\left(\mathrm{X}_{2}\right)$, intelektual $\left(\mathrm{X}_{3}\right)$, dan konsekuensial $\left(\mathrm{X}_{4}\right)$, terhadap etika berbisnis $(\mathrm{Y})$. Dari hasil pengujian diperoleh nilai probabilitas hitung $0,000<$ 0,05 atau probabilitas hitung < level of significance $(\alpha)$ atau $\mathrm{H}_{0}$ ditolak. Hal ini berarti bahwa variabel religiusitas yang diproksikan dengan ritual $\left(\mathrm{X}_{1}\right)$, ideologi $\left(\mathrm{X}_{2}\right)$, intelektual $\left(\mathrm{X}_{3}\right)$, dan konsekuensial $\left(\mathrm{X}_{4}\right)$ secara simultan berpengaruh positif dan signifikan terhadap etika berbisnis (Y). Berdasarkan analisis $F$ test tersebut, maka hipotesis penelitian yang berbunyi terdapat pengaruh signifikan dan positif secara simultan variabel religiusitas yang diproksikan dengan ritual $\left(\mathrm{X}_{1}\right)$, idelogi $\left(\mathrm{X}_{2}\right)$, intelektual $\left(\mathrm{X}_{3}\right)$, dan konsekuensial $\left(\mathrm{X}_{4}\right)$, terhadap etika berbisnis (Y) dapat diterima atau teruji kebenarannya.

Berdasarkan perbandingan standarized beta pada variabel bebas diperoleh nilai standarized beta dari ritual $\left(\mathrm{X}_{1}\right)$ adalah 0,304, ideologi $\left(\mathrm{X}_{2}\right)$ adalah 0,085 , intelektual $\left(\mathrm{X}_{3}\right)$ adalah 0,185 , dan konsekuensial $\left(\mathrm{X}_{4}\right)$ adalah 0,449 , maka dapat dinyatakan bahwa variabel yang memiliki pengaruh paling dominan 
adalah konsekuensial $\left(\mathrm{X}_{4}\right)$. Hal ini disebabkan konsekuensial $\left(\mathrm{X}_{4}\right)$ memiliki nilai standarized beta lebih tinggi dibandingkan variabel lainnya.

Brow et al. (2010) mengatakan bahwa religiusitas memberikan sumbangan yang cukup besar dalam membentuk perilaku etis dalam berbisnis. Perilaku etis ini tidak terlepas dari dua faktor penting yang mempengaruhinya, yaitu: pertama, faktor individual (seseorang), misal, masa kerja, usia, psikis, fisik, jenis kelamin dan motivasi berperilaku. Kedua, situasional atau lingkungan luar, misalnya suasana kerja, lingkungan kerja, dan lain sebagainya. Keinginan berperilaku etis merupakan salah satu keinginan manusia dalam berkehidupan. Keinginan-keinginan tersebut tidak dapat dilepaskan dari sifat manusia yang tidak pernah puas dan selalu ingin mendapatkan yang lebih dari yang telah didapatnya. Lingkungan juga ikut membentuk manusia dengan adanya interaksi dan internalisasi nilai-nilai. Dengan interaksi dan internalisasi nilai-nilai tersebut, manusia dapat berubah perilakunya yang akan berpengaruh pada aktivitas kerjanya.

\section{Pengaruh ritual/syari'ah terhadap etika berbisnis}

Keberagamaan atau religiusitas diwujudkan dalam berbagai sisi kehidupan manusia. Aktivitas beragama bukan hanya terjadi ketika seseorang melakukan peribadatan (ritual), tetapi juga ketika melakukan aktivitas lain yang didorong oleh kekuatan supranatural. Agama sebagai ajaran moral membentuk pribadi-pribadi yang kokoh dalam berperilaku, seperti kejujuran, kedisiplinan, kesetiakawanan, keoptimisan, semangat, dan toleran. Rasa keberagamaan seseorang (religiusitas) memiliki peran yang tidak kecil untuk memompa semangatnya dalam aktivitas bisnis (Epstein, 2002).

Hasil penelitian ini membuktikan bahwa ritual/ syari'ah berpengaruh positif dan signifikan terhadap etika berbisnis pada pebisnis R.M. Padang di Kota Malang. Hasil ini mendukung hasil penelitian Fauzan (2003). Seorang yang selalu taat melakukan ritual keagamaannya, misalnya sholatnya khusyu' akan berimplikasi terhadap aktivitas kerjanya, salah satunya adalah disiplin. Memiliki keyakinan terhadap keberadaan sang maha pencipta akan menumbuhkan sikap optimis dalam bekerja. Agustian (2001) mengemukakan bahwa manusia terdiri atas dua alam, yaitu alam sadar (fisik) dan alam bawah sadar (psikis). Wilayah fisik manusia hanya mampu menangkap apa yang dapat dilihat saja dan hanya melakukan aktivitas untuk mengikuti keadaan lingkungannya. Wilayah psikis erat hubungannya dengan mentalitas, sehingga kalau ada fenomena orang rajin sembahyang tetapi perbuatannya tidak sesuai dengan yang telah digariskan oleh agama, maka dapat diruntut akar persoalannya bahwa mereka melakukan sholat hanya pada wilayah fisik saja atau belum masuk ke dalam wilayah psikis. Oleh karena itu meskipun mereka telah melakukan sholat, zakat, korban, haji dan kegiatan ritual lainnya (fisik), tetapi hal tersebut masih belum cukup karena masih ada satu wilayah lagi yang harus dilaksanakan, yaitu psikis. Wilayah psikis ini arahnya adalah spiritual.

\section{Pengaruh ideologi/akidah terhadap etika berbisnis}

Hasil penelitian menunjukkan bahwa ideologi/ akidah tidak mempengaruhi etika berbisnis pada RM. Padang di Kota Malang, artinya rasa keimanan dan kepercayaan kepada Allah belum sepenuhnya dapat membuat seseorang meyakini apa yang diperintahkan dan dijanjikan oleh Allah. Kepercayaan hanya sebatas kepercayaan, belum diyakini dengan benar. Berbeda dengan penelitian yang dilakukan oleh Barnett et al. (1996) dan Clark \& Dawson (1996) bahwa kepercayaan dan keyakinan serta rasa keberagamaan seseorang (personal religiousness) memiliki pengaruh pada ethical ideology seseorang. Konsep keyakinan ini juga tidak lepas dari kondisi mental, lingkungan, pendidikan seseorang dalam memahami ajaran-ajaran agamanya.

\section{Pengaruh intelektual/ilmu terhadap etika ber- bisnis}

Pemahaman yang benar terhadap agama dan pengamalan yang terus menerus terhadap keyakinan agamanya akan membedakan seseorang dengan orang lain. Tanpa adanya pemahaman yang benar dan pengamalan atas keyakinan agamanya, sebuah keniscayaan akan membentuk pribadi-pribadi yang terampil, inisiatif, memiliki jiwa kepemimpinan (leadership), bertanggung jawab, jujur, disiplin, setia kawan, optimis, semangat, toleran, dan lain-lain.

Pengetahuan dalam penelitian ini tidak memiliki pengaruh terhadap etika berbisnis seseorang. Hal ini tidak dapat dilepaskan dari cara pandang seseorang dalam memahami pengetahuan dan memfungsikan pengetahuannya dalam kehidupan sehari-hari, di antaranya kegiatan bisnis. Clark \& Dawson (1996) menyoroti peran keberagamaan seseorang terhadap pertimbangan etisnya. Menurut mereka, keberagamaan merupakan motivasi untuk bertindak etis.

Pengetahuan tentang keagamaan terkadang masih berada pada tataran mengetahui. Hal ini dapat dilihat dari pernyataan yang ada yang hanya sebatas mengetahui tanpa ada kewajiban untuk mengimple- 
mentasikan pengetahuan itu dalam kehidupan seharihari. Ajaran-ajaran agama hanya sebatas untuk diketahui, tanpa ada tanggung jawab moral terhadap terlaksananya ajaran tersebut di masyarakat.

\section{Pengaruh konsekuensial/akhlaq terhadap etika berbisnis}

Perilaku seseorang dalam bekerja yang disebabkan oleh rasa keberagamaan (religiusitas) akan meningkatkan perilaku etisnya (Barnett et al., 1996; Clark \& Dawson, 1996). Meningkatnya perilaku etis tersebut, diharapkan tujuan keberadaan bisnis akan tercapai, dan memperoleh kepuasan sebagaimana orientasi awal dalam berbisnis.

Penelitian ini membuktikan bahwa dimensi pengamalan (konsekuensial/akhlaq) merupakan dimensi yang paling berpengaruh secara dominan terhadap etika berbisnis pada RM. Padang di Kota Malang. Pengamalan merupakan praktik langsung ajaran-ajaran serta nilai-nilai agama yang langsung tampak dalam kehidupan. Penelitian ini mendukung Barnett et al. (1996) dan Clark \& Dawson (1996) bahwa perilaku etis seseorang dipengaruhi oleh personal religiousness yang teraktualisasi dalam sikap hidup sehari-hari. Perilaku suka menghargai, menempatkan karyawan di atas segalanya, kejujuran, suka berderma merupakan aspek-aspek konsekuensial/akhlaq. Religiusitas yang diwakili oleh pengamalan/akhlaq ini menempatkan manusia pada aktualisasi diri manusia, artinya manusia yang baik adalah manusia yang memiliki makna bagi manusia yang lainnya.

\section{SIMPULAN DAN SARAN}

Berdasarkan pembahasan pada bab-bab sebelumnya, selanjutnya dapat dirumuskan beberapa kesimpulan sebagai berikut:

1. Religiusitas atau rasa keberagamaan walaupun tidak dominan, tetapi cukup mewarnai perilaku etis dalam bisnis rumah makan Padang. Pemilik rumah makan Padang mayoritas adalah pemeluk agama Islam, sehingga muatan-muatan ajaran Islam cukup mewarnai aktivitas bisnisnya.

2. Praktik berbisnis rumah makan Padang di Kota Malang berlandaskan pada perilaku etis yang didasarkan pada nilai-nilai dan ajaran agama yang dianut. Padang adalah daerah yang memiliki tradisi budaya yang cukup religius dan cukup konsisten dalam menjalankan ajaran-ajaran agamanya.

3. Ritual merupakan variabel yang mempengaruhi etika berbisnis rumah makan Padang di Kota
Malang. Seorang yang selalu taat melakukan ritual keagamaannya, misalnya sholatnya khusyu', akan berimplikasi terhadap aktivitas kerjanya, salah satunya adalah disiplin. Dengan memiliki keyakinan terhadap keberadaan sang maha pencipta akan menumbuhkan sikap optimis dalam bekerja.

4. Pengamalan (konsekuensial) memiliki pengaruh yang sangat positif dan signifikan serta merupakan dimensi yang paling dominan dalam mempengaruhi etika berbisnis pada bisnis RM. Padang di Kota Malang. Hal ini menunjukkan bahwa seseorang yang benar-benar menjalankan dan mengamalkan ajaran-ajaran agamanya akan memiliki sikap kesetiakawanan, toleran, bertanggung jawab baik antar sesama teman maupun terhadap atasan. Keluasan pengetahuan agama menumbuhkan sikap inisiatif dan kepemimpinan, sedangkan pengalaman-pengalaman keagamaan akan menumbuhkan sikap selalu menerima (qona'ah) terhadap apa yang telah diberikan oleh Tuhan kepadanya. Perilaku keberagamaan ini tidak diperoleh dengan begitu saja, namun melalui sebuah proses pembelajaran yang panjang.

5. Pengetahuan dan ideologi tidak memiliki pengaruh yang signifikan terhadap etika berbisnis rumah makan Padang di Kota Malang. Hal ini menunjukkan bahwa seseorang masih hanya sebatas pengetahuan, tetapi belum sepenuhnya mampu mengimplementasikan pengetahuan tersebut dalam kehidupan sehari-hari. Artinya seseorang belum sepenuhnya mau meyakini sistem kepercayaan yang telah dipegangnya sebagai sebuah keyakinan beragama.

Berdasarkan hasil penelitian, pembahasan, dan keterbatasan penelitian, maka dapat dikemukakan saran-saran sebagai berikut:

1. Secara normatif agama menciptakan sistem makna untuk mengarahkan perilaku kesalehan dalam kehidupan manusia. Pendidikan agama harus mampu memenuhi kebutuhan dasar, yaitu kebutuhan memenuhi tujuan agama untuk memberikan kontribusi terhadap terwujudnya kehidupan religiusitas. Diperlukan pemahaman konsep keberagamaan secara utuh, tidak hanya cukup pada tataran ritual/syari'ah saja.

2. Bagi pelaku bisnis rumah makan Padang, untuk keberlanjutan usaha tidak hanya cukup mengejar keuntungan semata, namun keyakinan akan kebenaran ayat-ayat Tuhan perlu diperhatikan kembali. Bersodaqoh, membayar zakat, serta pengamalan-pengamalan ajaran agama yang lain tidak boleh ditinggalkan begitu saja.

3. Bagi pelaku bisnis rumah makan Padang yang menginginkan keberlanjutan usahanya perlu 
mempertimbangkan aspek pendidikan. Pendidikkan merupakan sarana untuk lebih kreatif dan inovatif dalam mengembangkan bisnis.

4. Bagi peneliti lain yang akan meneliti tentang perilaku etis dalam berbisnis, cakupan penelitian hendaknya diperluas sehingga hasil penelitian dapat digeneralisasi. Perlu mempertimbangkan faktor-faktor lain baik eksternal maupun internal sebagai faktor yang ikut menentukan perilaku etis dalam berbisnis.

\section{DAFTAR REFERENSI}

Agustian, A. G. 2001. Rahasia Sukses Membangun Kecerdasan Emosi dan Spiritual ESQ Berdasarkan 6 Rukun Iman dan 5 Rukun Islam. Jakarta: Arga.

Ancok, D. 1994. Psikologi Islami: Solusi Islam Atas Problema-problema Psikologi. Jogjakarta: Pustaka Pelajar.

Arikunto, S. 2002. Prosedur Penelitian. Edisi Kelima. Jakarta: Rineka Cipta.

Barnett, T., Bass, K. \& Brown, G. 1996. Religiousity, Ethical Ideology, and Intentions to Report a Peer's Wrongdoing. Journal of Business Ethics, 15: 1161-1174.

Bertens, K. 2000. Pengantar Etika Bisnis. Yogyakarta: Kanisius.

Brow, T. A. et al. 2010. Ethics and Personality: Emphaty and Narcissism as Moderator of Ethical Decision Making in Business Students. Journal of Education for Business 85: 203-208.

Cavanagh, G. F. \& Bandsuch, M. R. 2002. Virtue as a Benchmark for Spirituality in Business, Journal of Business Ethics, 38: 109-117.

Clark, J. W. \& Dawson, L. E. 1996. Personal Religiousness and Ethical Judgements: An Empirical Analysis. Journal of Business Ethics, 15: 359-372.

Conroy, S. J. \& Emerson, T. L. N. 2002. Business Ethics in Knowledge Economy: The Role of Religiosity in Response to Ethical Situations, Journal of Business Ethics, 38: 164-173
Epstein, E. M. 2002. Religion and Business: The Critical Role of Religious Traditions in Management Education, Journal of Business Ethics, 38: 91-96.

Fauzan. 2003. Pengaruh Religiusitas terhadap Prestasi Kerja PNS Alumni dan Bukan Alumni Pesantren di Kantor Depag Kota Malang. Tesis tidak dipublikasikan Universitas Islam Indonesia Yogyakarta.

Ghozali, I. 2005. Aplikasi Analisis Multivariate dengan Program SPSS. Semarang: Badan Penerbit UNDIP.

Kartawiria, R. 2004. Spiritualitas Bisnis. Bandung: Hikmah.

Lovell, A. 2002. Ethics as Dependent Variable in Individual and Organizational Decision Making. Journal of Business Ethics, 37: 145-163.

Ludigdo, U. 2005. Pemahaman Strukturasi atas Praktik Etika disebuah Kantor Akuntan Publik, Disertasi tidak dipublikasikan Universitas Brawijaya Malang.

Ludigdo, U. \& Maryani, T. 2001. Survey atas FaktorFaktor yang Mempengaruhi Sikap dan Perilaku Etis Akuntan, Jurnal TEMA, II(1): 49-62.

Muhni, J. A. I. 1994. Moral dan Religi: Menurut Emile Durkheim dan Henri Bergson. Yogyakarta: Kanisius.

Port, S. J. 2005. Religion, Spirituality and Business Decision-Making: A Preliminary Investigation. Journal of Business Ethics, 40: 155-173.

Sugiyono, 2005. Metode Penelitian untuk Bisnis. Cetakan Kesembilan. Bandung: CV. Alfabeta.

Suhardiyanto. 2001. Pendidikan Religiusitas. Yogjakarta: Kanisius.

Suseno, F. M. 1987. Etika Dasar: Masalah-masalah Pokok Filsafat Moral. Yogyakarta: Kanisius.

Titus, et al. 1984. Persoalan-persoalan Filsafat. Jakarta: Bulan Bintang.

Tjahjadi, L. 1991. Hukum Moral: Ajaran Immanuel Kant tentang Etika dan Imperatif Kategoris. Yogyakarta: Kanisius.

Weaver, G. R. \& Agle, B. R. 2002. Religiousity and Behavior in Organizations: A Symbolic Interactionist Perspective. Academy of Management Review, 27(1): 77-97. 